\title{
Analisis Pengaruh Modal, Usia, dan Pendidikan Terhadap Pendapatan Pelaku Usaha Skala Mikro (Studi Pedagang Kaki Lima di Kelurahan Gading Kasri, Kota Malang)
}

\author{
Aryanto Nyuru Keiku, Harsono, Arif Dwi Hartanto
}

Aryanto Nyuru Keiku; Harsono; Arif Dwi Hartanto; Fakultas Ekonomi dan Bisnis Universitas Merdeka Malang; Jl. Terusan Raya Dieng 62-64 Malang, Jawa Timur; Indonesia.

ARTICLE INFO

\begin{tabular}{l}
\hline Article history: \\
Received 2019-13-12 \\
Received in revised form 2020-01-14 \\
Accepted 2020-02-01 \\
\hline Kata kunci: \\
Pendapatan, Pedagang \\
Kaki Lima, Modal, Usia, \\
Pendidikan \\
\hline Keywords: \\
Income, Street Vendors, \\
Capital, Age, Education. \\
\hline How to cite item: \\
Aryanto Nyuru Keiku, \\
Harsono, Arif Dwi \\
Hartanto. (2020). Analisis \\
Pengaruh Modal, Usia, dan \\
Pendidikan Terhadap \\
Pendapatan Pelaku Usaha \\
Skala Mikro (Studi \\
Pedagang Kaki Lima di \\
Kelurahan Gading Kasri, \\
Kota Malang). Journal of \\
Regional Economics \\
Indonesia, 1(1).
\end{tabular}

\section{Abstrak}

Penelitian ini bertujuan untuk mengetahui pengaruh variabel modal, usia, dan pendidikan terhadap pendapatan Pedagang Kaki Lima (PKL) di Kelurahan Gading Kasri Kota Malang. Penelitian ini berjenis kuantitatif yang bertujuan untuk memperoleh pembuktian dari sebuah hipotesis. Pengumpulan data dilakukan dengan cara wawancara dan penyebaran kuesioner serta pengamatan langsung. Sampel yang digunakan sebanyak 20 PKL dengan teknik sampling acak sederhana (simple random sampling). Analisis data menggunakan analisis regresi linier berganda. Hasil penelitian yang memakai uji terhadap koefisien regresi secara parsial (uji $t$ ) dengan $a=5 \%$ menunjukkan ketiga variabel (modal, usia dan pendidikan) berpengaruh positif dan signifikan terhadap pendapatan PKL di Kelurahan Gading Kasri Kota Malang. Hasil Uji F dengan a $=5 \%$ menunjukkan bahwa secara bersama-sama variabel modal, usia dan pendidikan berpengaruh terhadap pendapatan PKL di Kelurahan Gading Kasri Kota Malang. Berdasarkan hasil penelitian yang telah dilakukan, maka disarankan pendapatan usaha PKL sebagai pelaku usaha skala mikro dapat ditingkatkan dengan cara meningkatkan modal usaha dan keterampilan.

\section{Abstract}

This study aims to determine the effect of variable capital, age, and education on street vendor income (PKL) in Gading Kasri Kelurahan, Malang. This type of quantitative research aims to obtain evidence from a hypothesis. Data collection was carried out by interviewing and distributing questionnaires and direct observation. The sample used was 20 PKL with simple random sampling techniques. Data analysis uses multiple linear regression analysis. The results of the study using a partial test of the regression coefficient ( $t$ test) with $a=5 \%$ showed that the three variables (capital, age and education) had a positive and significant effect on street vendors' income in Gading Kasri Kelurahan, Malang. The results of the F Test with $a=5 \%$ indicate that together the variables of capital, age and education affect the income of street vendors in Gading Kasri Urban Malang. Based on the results of research that has been done, it is suggested that street vendors' business income as micro scale businesses can be increased by increasing business capital and skills.

\section{Latar Belakang}

Pelaku usaha skala mikro dimaknai sebagai unit usaha yang rata-rata dicirikan dengan sifat padat karya dan membutuhkan modal yang relatif kecil (Aloum, et.al, 2016). Pendapat lain menyatakan bahwa pelaku usaha skla mikro adalah unit usaha yang rata-rata dicirikan dengan model

* Aryanto Nyuru Keiku, Harsono, Arif Dwi Hartanto. (C) 2020 University of Merdeka Malang All rights reserved.

Peer review under responsibility of University of Merdeka Malang All rights reserved. 
produksi yang sederhana tanpa mensyaratkan keterampilan yang terlampau tinggi. Kesederhanaan produksi tercermin dari sifat manajemen yang tradisional dan cara bersikap (orientasi bisnis) dari para pelakunya yang bertendensi konservatif (Mutoko\& Kapunda, 2017). Sifatsifat tersebut berkorelasi dengan skala usaha yang bersifat mikro, yang berbeda dengan skala usaha kecil dan menengah. Perbedaan ketiganya biasanya terletak pada perbedaan omset, jumlah tenaga kerja, dan nilai aset/modal usaha. Pada skala usaha mikro, omset yang diperoleh sangat kecil, permodalan terbatas, aset terlampau kecil, dan perolehan omset yang rata-rata masih di bawah standar hidup minimum.

Meski melekat dengan segala keterbatasan, namun eksistensi pelaku usaha skala mikro juga sangat penting bagi perekonomian. Keberadaan unit usaha skala mikro rata-rata mampu menampung tenaga kerja, tahan terhadap krisis, dan tingkat permintaan pasar yang cenderung stabil (Mustapa, Mamun\& Ibrahim, 2018). Menurut Njoroge (2013), peranan pelaku usaha skala mikro di berbagai negara, khususnya negara berkembang rata-rata didorong melalui penyerapan angkatan kerja yang tidak tertampung di sektor formal. Meski dengan pendapatan rendah, namun setidaknya mampu menjadi sumber pendapatan dengan probabilitas kenaikan yang bisa ditingkatkan. Berdasarkan peranan tersebut, maka pengembangan usaha para pelaku skala mikro menjadi sangat penting dilakukan. Pemangku kepentingan, khususnya pemerintah sangat berkepentingan terhadap percepatan pertumbuhan unit usaha skala mikro karena peranannya yang krusial sebagai penampung angkatan kerja dan pengentasan kemiskinan. Percepatan tersebut ditujukan dalam rangka meningkatkan daya saing pelaku skala mikro agar usaha yang dijalankan dapat bertahan dalam jangka panjang.

Salah satu indikator utama untuk menilai keberlangsungan usaha dalam jangka panjang adalah melalui peningkatan keuntungan usaha. Kesejahteraan pelaku usaha mikro dapat diukur dari tingkat pendapatan. Radipere\& Dhliwayo (2019) menyatakan variabel-variabel penentu tingkat pendapatan pelaku usaha mikro, diantaranya adalah besaran nilai modal, usia, dan tingkat pendidikan. Modal merupakan aspek yang sangat penting dalam rangka meningkatkan kapasitas produksi maupun pemasaran. Sementara usia rata-rata mampu menentukan keberhasilan 
usaha, yang dilihat dari sisi pengalaman usaha. Sementara menurut Raposo\& Paco (2011), tingkat pendidikan pelaku usaha sangat menentukan kualitas perencanaan usaha, sehingga mampu berdampak pada tingkat keuntungan yang diperoleh.

Namun demikian, beberapa penelitian seperti dikemukakan oleh Obebo, Wawiwe\& Miniu (2018), menemukan bahwa pengaruh tingkat pendidikan bukan sebagai variabel determinan keberhasilan usaha pelaku skala mikro. Lateh, Hussain\& Halim (2017) menyatakan bahwa usia bukan faktor penentu dalam menghasilkan pendapatan yang tinggi. Usia muda yang inovatif, meskipun minim pengalaman mempunyai peluang yang lebih besar dalam merebut pangsa pasar. Kondisi serupa juga berlaku pada tingkat modal, dimana permodalan yang lebih kecil namun mampu dikelola dengan baik akan menghasilkan pendapatan yang gradual dan berkelanjutan dibandingkan permodalan yang besar namun dengan tata kelola yang buruk.

Dalam kasus di atas, terjadi perdebatan antara pengaruh modal, usia, dan tingkat pendidikan terhadap perolehan tingkat pendapatan. Maka dari itu, penelitian ini bertujuan untuk mengnalisis pengaruh tingkat modal, usia, dan tingkat pendidikan terhadap pendapatan yang diperoleh oleh pelaku usaha skala mikro. Kasus yang diangkat adalah kelompok Pedagang Kaki Lima (PKL) di Kelurahan Gading Kasri, Kota Malang. Masyarakat di Kelurahan Gading Kasri mempunyai komposisi yang tinggi yang bekerja sebagai PKL. Para pelaku PKL merepresentasikan usaha skala mikro karena mempunyai beragam karakteristik yang masih tradisional. Berdasarkan uraian tersebut, maka penelitian ini penting dilakukan dalam rangka menguatkan argumentasi empiris mengenai pengaruh antara modal, usia, dan tingkat pendidikan terhadap pendapatan yang diperoleh para pelaku usaha skala mikro.

\section{Tujuan Penelitian}

Berdasarkan latar belakang, maka tujuan penelitian ini adalah sebagai berikut:

1. Untuk mendeskripsikan modal, usia, tingkat pendidikan dan pendapatan pedagang kaki lima di Kelurahan Gading Kasri Kota Malang. 
2. Untuk menganalisis pengaruh modal, usia, dan tingkat pendidikan terhadap pendapatan pedagang kaki lima di Kelurahan Gading Kasri Kota Malang.

3. Untuk menganalisis diantara variabel modal, usia dan pendidikan yang berpengaruh dominan terhadap pendapatan pedagang kaki lima di Kelurahan Gading Kasri Kota Malang.

\section{Landasan Teori}

\section{A. Konsep Pendapatan}

Menurut Sukirno (2000), pendapatan adalah unsur yang sangat penting dalam sebuah usaha, dimana pendapatan menentukan tingkat keberhasilan usaha. Dalam kasus Pedagang Kaki Lima (PKL), tingkat pendapatan yang diperoleh sama dengan pelaku usaha pada umumnya, yaitu dapat dilihat melalui penerimaan total (total revenue) yang diperoleh. Penerimaan total (Total Revenue) merupakan penerimaan total produsen dari setiap penjualan output yang dihasilkannya. Penerimaan ini dapat dihitung dengan cara mengalikan jumlah seluruh barang yang terjual dengan harga jual barang per unit.

Waluyo (2013) mengemukakan bahwa tingkat pendapatan seseorang tu entitas pelaku usaha dapat dibedakan menjadi dua jenis, yaitu pendapatan nominal dan pendapatan riil. Pendapatan nominal merupakan pendapatan yang diterima oleh seseorang dalam jumlah nominal. Sedangkan pendapatan riil merupakan pendapatan yang jumlahnya telah dideflasikan dengan perubahan harga barang dan jasa. Pendapatan riil merupakan indikator yang paling realistis digunakan untuk mengukur tingkat kesejahteraan. Sementara Soekartawi (2002) menjelaskan pendapatan akan mempengaruhi banyaknya barang yang dikonsumsikan. Dengan bertambahnya tingkat pendapatan, maka barang yang dikonsumsi bukan saja bertambah, tapi juga kualitas barang tersebut juga akan meningkat. Menurut Kurniawan (2016), dalam kasus PKL, pengukuran besar kecilnya pendapatan diukur melalui faktor-faktor dari kinerja PKL berdasarkan variabel-variabel umur, tingkat pendidikan, jam kerja, pengalaman kerja, modal, dan jumlah pekerja. 


\section{B. Faktor yang Mempengaruhi Pendapatan}

Pada hakikatnya, pendapatan yang diterima oleh seseorang maupun badan usaha tentunya dipengaruhi oleh banyak faktor, seperti tingkat pendidikan dan pengalaman seorang. Semakin tinggi tingkat pendidikan dan pengalaman, maka probabilitas perolehan tingkat pendapatan yang diperoleh akan semakin tinggi. Selain itu, tingkat pendapatan juga dipengaruhi oleh modal usaha, jam kerja, jumlah tenaga kerja, jenis barang dagangan (produk) dan faktor lainnya. Sementara menurut Lateh, Hussain\& Halim (2017), penentu tingkat pendapatan pada pelaku usaha sangat dipengaruhi oleh tingkat manajemen, pengalaman, permodalan, tingkat pendidikan,dan orientasi bisnis yang dijalankan. Pada umumnya pelaku usaha selalu mencari tingkat pendapatan tinggi dalam rangka melakukan ekspansi usaha, akan tetapi dibatasi oleh beberapa faktor penghambat sebagai variabel penentu tingkat pendapatan.

Menurut Yuliani (2011), terdapat berbagai faktor yang menjadi penyebab terjadinya ketimpangan pendapatan.

1. Pertama adalah faktor usia, dimana pekerja muda biasanya masih terbatas keterampilan dan pengalamannya. Produk fisik marjinal mereka lebih rendah daripada rata-rata produk fisik marjinal yang dihasilkan oleh para pekerja yang lebih berumur dan berpengalaman. Karakteristik bawaan, besarnya pendapatan kalangan tertentu besarnya sangat ditentukan oleh karakteristik bawaan mereka. Meski demikian, besar kecilnya tingkat pendapatan yang dihubungkan dengan karakteristik bawaan sejauh ini masih diperdebatkan, apalagi keberhasilan seseorang seringkali dipengaruhi oleh kondisi lingkungan dan masyarakatnya.

2. Kedua adalah ketidapastian dan variasi pendapatan, yaitu bidangbidang kerja yang hasilnya serba tidak pasti, misalnya bidang kerja pemasaran, mengandung risiko yang lebih besar sehingga mempengaruhi tingkat pendapatan yang diperoleh. Mereka yang menekuni bidang itu dan berhasil, akan menuntut dan menerima pendapatan yang lebih besar, melebihi mereka yang bekerja di bidang-bidang yang lebih aman. Pernyataan tersebut diperkuat oleh Gimmon, Yitsaki\& Hantman (2018), bahwa karakteristik pekerjaan dan usaha yang dijalankan akan mempengaruhi tingkat 
pendapatan, dimana karakteristik yang dimaksud berkaitan dengan besaran risiko yang dihasilkan.

\section{Konsep Biaya}

Dalam konteks bisnis, biaya adalah segala hal yang dikeluarkan dalam rangka menghasilkan output dalam skala tertentu (Obebo, Wawiwe\& Muniu, 2018). Biaya produksi merupakan semua beban yang harus dikeluarkan oleh produsen dalam rangka menghasilkan suatu barang/produksi. Dalam teori biaya, dikenal berbagai macam biaya dan dibedakan menurut jangka waktunya, yaitu jangka pendek dan jangka panjang. Dalam teori jangka pendek maupun jangka panjang dikenal istilah biaya (fixed cost) tetap dan biaya variabel (variable cost).

Biaya tetap ialah biaya yang besarnya tidak tergantung pada hasil produksi, artinya biaya tetap dikeluarkan dengan jumlah sama meskipun hasil produksi mengalami penurunan, atau bahkan peningkatan. Sedangkan biaya variabel ialah biaya yang besarnya berubah-ubah mengikuti tingkat produksi, artinya biaya ini akan semakin banyak dikeluarkan apabila produksi yang dihasilkan semakin meningkat. Pengaturan biaya tetap dan biaya variabel akan menentukan besar kecilnya tingkat keberhasilan dalam melakukan skala produksi.

Pada teori biaya produksi periode jangka panjang, semua biaya bersifat variabel (berubah-ubah). Sedangkan pada periode jangka pendek biaya bersifat tetap (tidak berubah). Namun hal ini tidak menutup kemungkinan bahwa biaya tetap pada periode jangka pendek juga akan mengalami perubahan. Hal ini dikarenakan faktor-faktor tertentu yang harus menambah beban biaya. Contohnya perusahaan yang lebih maju, maka tambahan biaya tetap dalam jangka waktu tersebut memang harus dikeluarkan. Biaya tersebut berkaitan dengan penerimaan total (Total Revenue), yaitu pendapatan yang diperoleh dari hasil penjualan produk.Untuk pasar persaingan sempurna, TR berkaitan dengan asumsi bahwa pembeli dan penjual di pasar persaingan sempurna merupakan pengikut harga (price takers). Harga ditentukan oleh kekuatan pasar, sementara penjual dan pembeli tidak dapat mempengaruhi harga. Penjual dan pembeli disamping menjadi quantity setters, juga sebagai price takers. 


\section{Metode Penelitian}

\section{A. Identifikasi Variabel}

Variabel dalam penelitian ini adalah pendapatan (Y) Pedagang Kaki Lima (PKL) di Kelurahan Gading Kasri sebagai variabel terikatnya, modal (X1), usia (X2) dan pendidikan (X3) sebagai variabel bebas.

1. Pendapatan $(\mathrm{Y})$

Menurut Soekartawi (2002), pendapatan akan mempengaruhi banyaknya barang yang dikonsumsikan, bahwa dengan bertambahnya pendapatan, maka barang yang dikonsumsi bukan saja bertambah, tapi juga kualitas barang tersebut akan meningkat. Dalam penelitian ini, Pendapatan (Y) adalah nilai uang yang didapat PKL di Kelurahan Gading Kasri dari usahanya dengan satuan rupiah per hari.

2. Modal (X1)

Menurut Adhiatma (2015), modal adalah semua bentuk kekayaan yang dapat digunakan langsung maupun tidak langsung dalam proses produksi. Dalam penelitian ini modal yang di maksud adalah modal harian, yaitu uang yang digunakan untuk berbelanja bahan baku oleh PKL di kelurahan Gading Kasri dalam rangka kegiatan produksi perhari, yang diukur dengan satuan rupiah.

3. Usia $(\mathrm{X} 2)$

Menurut Hurlock (1998), semakin cukup usia, tingkat kematangan dan kekuatan seseorang akan lebih matang dalam berfikir dan bekerja. Dalam penelitian ini, usia adalah tahun PKL selaku responden pada saat penelitian dilakukan, yang diukur dalam tahun.

4. Pendidikan (X3)

Menurut Siagian (2006), pendidikan adalah keseluruhan proses teknik dan metode belajar mengajar dalam rangka mengalihkan suatu pengetahuan dari seseorang kepada orang lain sesuai dengan standar yang telah ditetapkan. Dalam penelitian ini, pendidikan adalah jumlah tahun sukses yang pernah dijalani responden dalam jenjang pendidikan formal. Tingkat pendidikan diukur dengan skor yaitu : Tidak sekolah $=0, \mathrm{SD}=1, \mathrm{SMP}=2, \mathrm{SMA}=3, \mathrm{~S} 1=4$. 


\section{B. Lokasi Penelitian dan perolehan Data}

Penelitian ini menekankan pada pendapatan Pedagang Kaki Lima (PKL) di Kelurahan Gading Kasri Kota Malang yang dikaitkan dengan variabel modal, usia dan pendidikan terhadap pendapatan PKL di Kelurahan Gading Kasri, Kota Malang. Berdasarkan karakter tersebut, maka jenis data yang digunakan dalam penelitian ini adalah data kuantitatif yang bersumber dari data sekunder dan data primer. Data sekunder diperoleh langsung dari Kantor Kelurahan Gading Kasri Kota Malang, dan data primer diperoleh secara langsung melalui angket dan wawancara dengan PKL di Kelurahan Gading Kasri Kota Malang menggunakan daftar pertanyaan berupa kuesioner.

\section{Teknik Analisis}

1. Analisis Deskriptif

Statistik deskriptif digunakan untuk menganalisis karakteristik sampel, yang didalamnya dapat nilai - nilai variabel seperti mean (rata - rata). Deviasi standar adalah cara pengukuraan lain dari penyebaran, dimana lebih biasa untuk digunakan dan merupakan kulkulasi yang sederhana. Nilai maksimum adalah nilai terbesar yang digunakan dalam sampel penelitian, sedangkan nilai minimun adalah nilai terkecil yang digunakan sebagai sampel dalam penelitian.

2. Analisis regresi linear berganda

Analisis ini digunakan untuk menganalisis faktor-faktor yang mempengaruhi tingkat pendapatan PKL di Kelurahan Gading Kasri, dan dapat dirumuskan dengan model fungsi sebagai berikut:

$\mathrm{Y}=\mathrm{F}\left(\mathrm{X}_{1} \mathrm{X}_{2} \mathrm{X}_{3}\right)$

Dimana $: Y=$ Pendapatan PKL

$$
\begin{aligned}
& X_{1}=\text { Modal } \\
& X_{2}=\text { Usia } \\
& X 3=\text { Pendidikan }
\end{aligned}
$$

Dari rumus tersebut kemudian diturunkan menjadi persamaan regresi, yaitu :

$Y=\beta_{0}+\beta_{1} X_{1}+\beta_{2} X_{2}+\beta_{3} X_{3}+e$

Dimana: $\quad Y \quad=$ pendapatan PKL

$\beta_{0} \quad=$ intersep $/$ konstanta 


$$
\begin{array}{ll}
\beta_{1} \beta_{2} \beta_{3} & =\text { koefisien regresi } \\
X_{1} & =\text { modal } \\
X_{2} & =\text { usia } \\
X_{3} & =\text { pendidikan } \\
\mathrm{E} & =\text { variabel pengganggu }
\end{array}
$$

Pengujian hipotesis lanjut dari perolehan koefisien regresi diatas peneliti menguji dengan uji $\mathrm{t}$, uji $\mathrm{F}$ dan uji asumsi klasik.

a. Uji Asumsi Klasik

1) Uji Normalitas

Uji normalitas bertujuan untuk mengetahui normal atau tidaknya suatu distribusi data. Uji normalitas menjadi hal yang penting karena salah satu syarat pengujian parametrictest (uji parametrik) adalah data yang harus memiliki distribusi normal (Sarjono, 2011)..

2) Uji Heterokedatisitas

Uji heterokedatisitas menunjukkan bahwa varians variabel tidak sama untuk semua pengamatan/observasi. Jika varians dari residual satu pengamatan ke pengamatan yang lain tetap maka homokedatisiras. Ada beberapa cara untuk mendeteksi ada tidaknya heterokedatisitas yaitu dengan melihat scatterplot atau melalui Uji Gletjer, Uji Park, dan Uji White, akan tetapi yang banyak digunakan yaitu menggunakan scatterplot.

3) Uji Multikolerasi

Uji multikorelasi bertujuan untuk hubungan apakah hubungan diantara variabel bebas memiliki masalah multikorelasi (gejala multikorelasi) atau tidak. Uji multikorelasi perlu dilakukan apabila jumlah variabel independen (variabel bebas) lebih dari satu (Wijaya, 2009). Uji multikorelasi yang sering digunakan yaitu dengan melihat VIF, karena yang paling mudah dan praktis.

b. Signifikansi Simultan (Uji F)

Uji F pada dasarnya menunjukkan apakah semua variabel independen yang dimasukkan dalam model mempunyai pengaruh secara bersama-sama terhadap variabel dependen. Hipotesisnya adalah: 
$\mathrm{H} 0: \beta 1=\beta 2=\beta 3=0$, semua variabel bebas tidak mempengaruhi variabel terikat secara simultan dengan signifikan.

Ha : $\beta 1 \neq \beta 2 \neq \beta 3 \neq 0$, semua variabel bebas mampu mempengaruhi variabel terikat secara simultan dengan signifikan.

Kriteria pengujian:

4) Jika hasil uji probabilitas $\leq a(0.05)$, di mana a merupakan besarnya kesalahan yang ditolerir di dalam pengambilan keputusan maka $\mathrm{H} 0$ ditolak dan Ha diterima.

5) Jika hasil uji probabilitas $>a(0.05)$, di mana a merupakan besarnya kesalahan yang ditolerir di dalam pengambilan keputusan maka $\mathrm{H} 0$ diterima dan Ha ditolak

c. Uji Parsial (Uji t)

Uji statistik $t$ pada dasarnya menunjukkan seberapa jauh pengaruh satu variabel independen secara individual dalam menerangkan variasi variabel dependen. Uji $t$ ini digunakan hipotesis sebagai berikut:

Ho : $\beta \mathrm{i}=0$

Ha: $\beta \mathrm{i} \neq 0$

Dimana $\beta \mathrm{i}$ adalah koefisien variabel independen ke-I yaitu nilai parameter hipotesis. Jika nilai $\beta=$ nol, artinya tidak ada pengaruh variabel Xi terhadap Y. Bila nilai thitung lebih besar dari t.tabel maka pada t.hitung dengan tingkat kepercayaan tertentu, Ho ditolak. Hal ini berarti bahwa variabel independen yang diuji berpengaruh secara nyata terhadap variabel dependen, nilai thitung diperoleh dengan rumus :

$$
\text { thitung }=\frac{\beta \mathrm{i}}{\mathrm{S} \beta \mathrm{i}}
$$

di mana:

$\beta \mathrm{i}=$ koefisien variabel bebas

$S \beta \mathrm{i}=$ standart deviasi

Untuk mengetahui signifikasi dari masing-masing variabel telah ditetapkan hipotesis sebagai berikut:

Hipotesis umur 
H0 : $\beta 1=0$, Berarti jumlah umur tidak berpengaruh signifikan terhadap pendapatan

Ha : $\beta 1 \neq 0$, Berarti jumlah umur berpengaruh signifikan terhadap pendapatan

Hipotesis pendidikan

H0 : $\beta 2=0$, Berarti jumlah pendidikan tidak berpengaruh signifikan terhadap pendapatan

Ha : $\beta 2 \neq 0$, Berarti jumlah tingkat pendidikan berpengaruh signifikan terhadap pendapatan

Hipotesis modal

$\mathrm{H} 0: \beta 3=0$, Berarti jumlah modal tidak berpengaruh signifikan terhadap pendapatan

Ha : $\beta 3 \neq 0$, Berarti jumlah modal berpengaruh signifikan terhadap pendapatan.

Kriteria pengambilan keputusan:

1) Jika nilai hasil uji probabilitas $\leq a(0.05)$, di mana $a$ merupakan besarnya kesalahan yang ditolerir di dalam pengambilan keputusan maka $\mathrm{H} 0$ ditolak dan Ha diterima.

2) Jika nilai hasil uji probabilitas $>a(0.05)$, di mana $a$ merupakan besarnya kesalahan yang ditolerir di dalam pengambilan keputusan maka $\mathrm{H} 0$ diterima dan Ha ditolak.

\section{Hasil Penelitian}

\section{A. Deskripsi Masing-Masing Variabel}

Deskripsi masing-masing variabel bertujuan untuk mendeskripsikan dan menguji pengaruh antara variabel bebas dan variabel terikat. Deskripsi data yang akan disajikan adalah mencakup nilai minimal, nilai maksimal, mean, dan median.

Tabel 01. Variabel Pendapatan, Modal, Usia, dan Pendidikan

\begin{tabular}{|c|c|c|c|c|c|}
\hline & & PENDAPATAN & MODAL & USIA & PENDIDIKAN \\
\hline $\mathrm{N}$ & Valid & 20 & 20 & 20 & \\
\hline & Missing & 0 & 0 & 0 & \\
\hline Mean & & 251.25 & 592.50 & 44.30 & 1.90 \\
\hline Median & & 200.00 & 650.00 & 45.00 & 2.0 \\
\hline
\end{tabular}




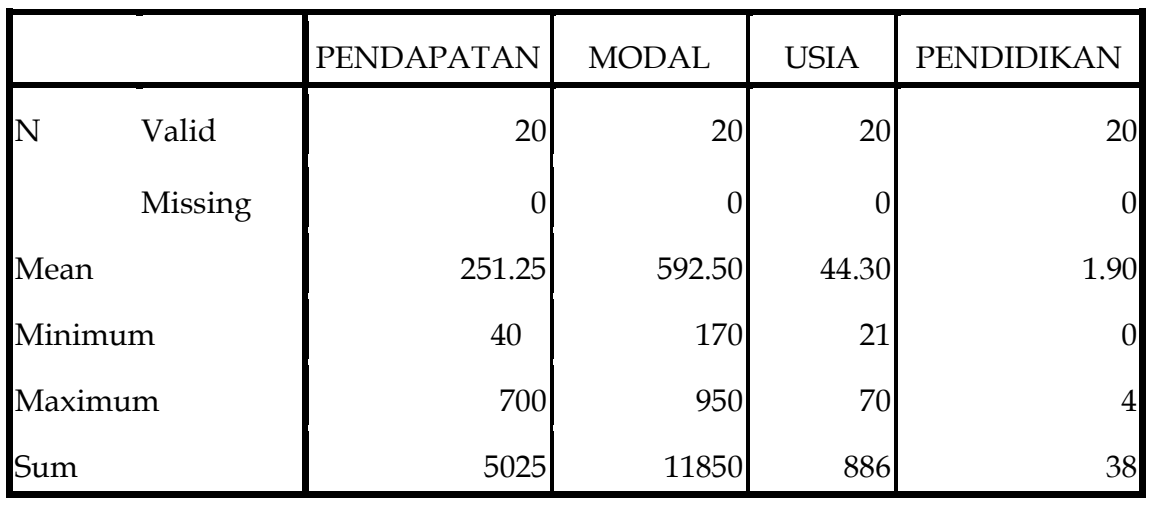

a. Multiple modes exist. The smallest value is shown

Sumber: Data Primer Diolah, 2019

Dalam hasil uji analisisi deskriptif, dapat dilihat data sebagai berikut :

a. Pada variabel Modal (X1), memiliki Nilai Mean sebesar 592.50, Nilai Median sebesar 650.00, Nilai minimum sebesar 170, dan Nilai Maximum sebesar 950. Kondisi tersebut menggambarkan besarnya pengaruh variabel Modal (X1) terhadap Variabel Pendapatan Pedagang (Y).

b. Pada variabel Usia (X2), memiliki Nilai Mean sebesar 44.30, Nilai Median sebesar 45.00, Nilai minimum sebesar 21, dan Nilai Maximum sebesar 70. Kondisi tersebut menggambarkan besarnya pengaruh variabel Usia (X2) terhadap Variabel Pendapatan Pedagang (Y).

c. Pada variabel Pendidikan (X3), memiliki Nilai Mean sebesar 1.90, Nilai Median sebesar 2.00 Nilai minimum sebesar 0, dan Nilai Maximum sebesar 4. Kondisi tersebut menggambarkan besarnya pengaruh variabel Pendidikan (X3) terhadap Variabel Pendapatan Pedagang (Y).

d. Pada variabel Pendapatan (Y), memiliki Nilai Mean sebesar 251.25, Nilai Median sebesar 200.00, Nilai minimum sebesar 40, dan Nilai Maximum sebesar 700. Kondisi tersebut menggambarkan besarnya pengaruh variabel Modal (X1), Usia (X2), dan Pendidikan (X3), terhadap Variabel Pendapatan Pedagang (Y).

Hasil analisis deskriptif di atas menunjukan bahwa variabel Modal memiliki pengaruh yang sangat besar atau signifikan terhadap pendapatan PKLdi Kelurahan Gading Kasri Kota Malang. 
1. Pendapatan

Dari hasil analisis responden, pendapatan terendah sebesar Rp. 40.000, dan pendapatan tertinggi sebesar Rp. 700.000, dengan rata-rata sebesar Rp. 251.250, nilai tengah sebesar Rp. 200.000, modus sebesar Rp. 100.000, dan standar deviation sebesar Rp. 185.897. Hasil perhitungan ini dapat dibuat pada tabel deskripsi variabel pendapatan seperti berikut ini:

Tabel 02. Deskripsi Variabel Pendapatan

\begin{tabular}{|c|c|c|c|}
\hline No & $\begin{array}{c}\text { Pendapatan } \\
(\mathrm{Rp})\end{array}$ & $\begin{array}{c}\text { Jumlah } \\
\text { Responden }\end{array}$ & $\begin{array}{c}\text { Persen } \\
(\%)\end{array}$ \\
\hline 1. & $40.000-100.000$ & 7 & 35 \\
\hline 2. & $100.001-300.000$ & 7 & 35 \\
\hline 3. & $300.001-700.000$ & 6 & 30 \\
\hline & Total & 20 & 100 \\
\hline
\end{tabular}

Sumber: Data Primer Diolah, 2019

2. Modal

Data variabel modal PKL di Kelurahan Gading Kasri dengan modal terendah sebesar Rp. 170.000, dan modal tertinggi Rp. 950.000, dengan rata-rata Rp. 592.500, median Rp. 650.000, modus Rp. 800.000 dan standar deviation Rp. 213.883. Hasil perhitungan ini dapat dibuat tabel deskripsi variabel modal seperti berikut ini:

Tabel 03. Deskripsi Variabel Modal

\begin{tabular}{|l|c|c|c|}
\hline No & $\begin{array}{c}\text { Modal } \\
(\mathrm{Rp})\end{array}$ & $\begin{array}{c}\text { Jumlah } \\
\text { Responden }\end{array}$ & $\begin{array}{c}\text { Persen } \\
(\%)\end{array}$ \\
\hline 1. & $100.000-300 / 000$ & 7 & 35 \\
\hline 2. & $300.001-600.000$ & 3 & 15 \\
\hline 3. & $600.001-950.000$ & 10 & 50 \\
\hline \multicolumn{2}{|c|}{ Total } & 20 & 100 \\
\hline
\end{tabular}

Sumber : Data Primer Diolah, 2019

Dapat diketahui bahwa modal awal yang dikeluarkan PKL dengan frekuensi terbesar yaitu sebanyak 10 responden atau sebesar 50\% yaitu modal antara Rp. 600,000-950,000. Sedangkan modal dengan frekuansi paling kecil antara Rp300,001-600,000 sebanyak 3 responden atau sebesar $15 \%$. 
3. Usia

Data variabel usia diperoleh dari hasil dokumentasi dan angket. Dari analisis diperoleh data terkait usia PKL Kelurahan Gading Kasri dengan usia terendah 21 tahun dan usia tertinggi 70 tahun, rata-rata usia 44,3 tahun, median 45,00 tahun, modus 50 tahun, dan standar deviasi13,530 tahun.

Tabel 04. Deskripsi Variabel Usia

\begin{tabular}{|l|c|c|c|}
\hline No & Usia & Jumlah Resonden & $\%$ \\
\hline 1. & $21-30$ & 3 & 15 \\
\hline 2. & $31-40$ & 7 & 35 \\
\hline 3. & $41-60$ & 9 & 45 \\
\hline 4. & $61-70$ & 1 & 5 \\
\hline \multicolumn{2}{|l|}{ Total } & 20 & 100 \\
\hline
\end{tabular}

Sumber: Data Primer Diolah, 2019

Usia PKL di Kelurahan Gading Kasri yang berusia produktif antara usia 21-60 tahun sebesar 85\%. Sedangkan untuk PKL lansia atau sudah tidak produktif sebesar 5\%. Hal ini menunjukkan bahwa PKL di Kelurahan Gading Kasri rata-rata masih berada dalam kelompok usia produktif. Kondisi tersebut menandakan mereka masih memiliki potensi yang besar untuk menghasilkan pendapatan.

4. Pendidikan

Data variabel pendidikan diperoleh dari hasil dokumentasi dan angket. Dapat diketahui bahwa tingkat pendidikan PKL di Kelurahan Gading Kasri dengan frekuensi terbesar yaitu sebanyak 7 respoden atau sebesar 35\% menempati kategori tamat SD. Responden yang frekuensi paling kecil responden tidak tamat SD dan S1 sebanyak 1 responden atau sebesar 5\%. Hal ini menunjukkan bahwa PKL di Kelurahan Gading Kasri sebagian besar berpendidikan SD atau berpendidikan rendah. 
Tabel 05. Deskripsi Variabel Pendidikan

\begin{tabular}{|l|c|c|c|}
\hline No & Pendidikan & $\begin{array}{c}\text { Jumlah } \\
\text { Responden }\end{array}$ & $\begin{array}{c}\text { Persen } \\
(\%)\end{array}$ \\
\hline 1. & Tidak Tamat SD & 1 & 5 \\
\hline 2. & Tamat SD & 7 & 35 \\
\hline 3. & Tamat SMP & 6 & 30 \\
\hline 4. & Tamat SMA & 5 & 25 \\
\hline 5. & S1 & 1 & 5 \\
\hline \multicolumn{2}{|c|}{ Total } & 20 & 100 \\
\hline
\end{tabular}

Sumber: Data Primer Diolah, 2019

\section{B. Hasil Analisis Data}

a. Uji Asumsi Klasik

1) Uji Normalitas

Gambar 01 menunjukkan bahwa data (titik) menyebar di sekitar dan mendekati garis diagonal. Ini menunjukkan bahwa variabel penelitian berdistribusi normal.

\section{Gambar 01. Hasil Uji Normalitas}

Normal P-P Plot of Regression Standardized Residual

Dependent Variable: PENDAPATAN

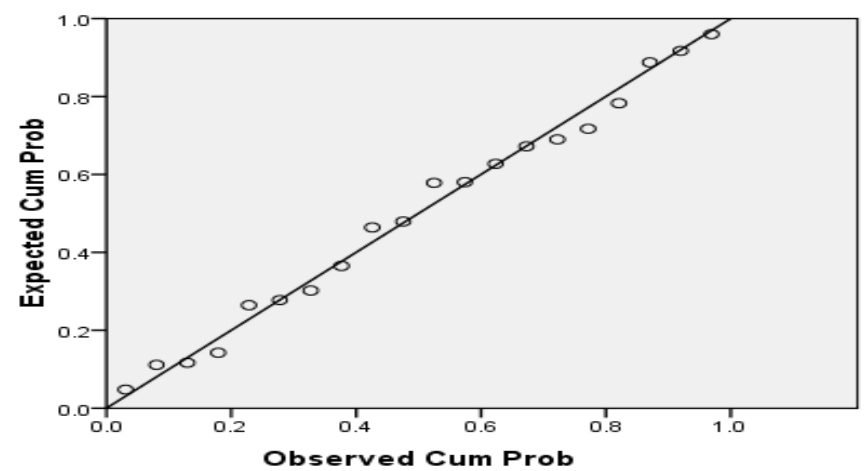

2) Uji Heterokedatisitas

Berdasarkan Gambar 02, terlihat titik-titik menyebar secara acak, tidak membentuk sebuah pola tertentu yang jelas, serta tersebar baik di atas maupun di bawah angka 0 pada sumbu y. Hal ini berarti tidak terjadi heteroskedastisitas pada model regresi. 


\section{Gambar 02. Hasil Uji Heterokedatisitas}

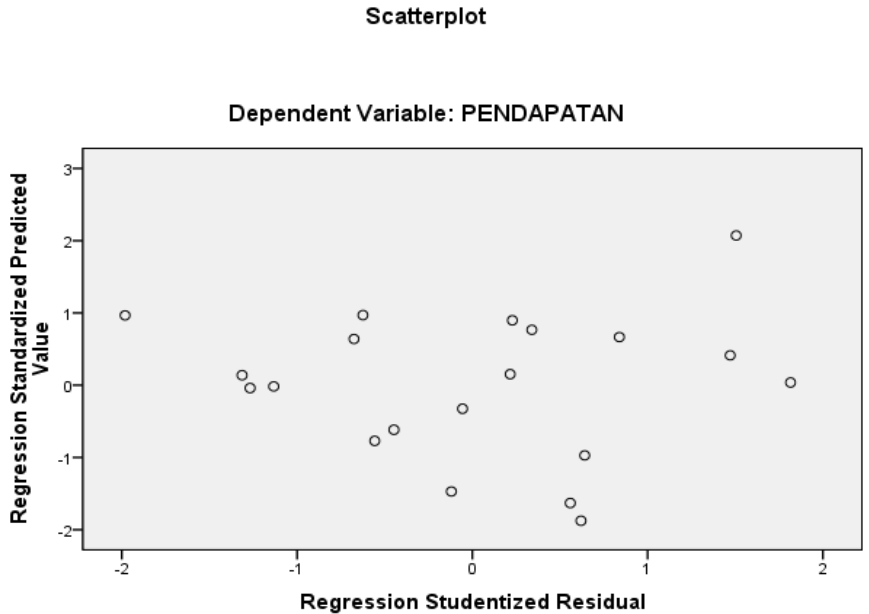

Sumber: Data Primer Diolah, 2019

3) Uji Multikolerasi

Berdasarkan hasil perhitungan VIF dapat disimpulkan bahwa tidak terjadi multikolinearitas pada model regresi linear berganda yang dibuat. Hal ini karena nilai VIF yang ada mempunyai nilai di atas angka 1 sehingga tidak melebihi batas VIF, yaitu 10.

\section{Tabel 05. Hasil Uji Multikolerasi}

\begin{tabular}{|r|r|}
\hline \multicolumn{3}{|c|}{ Collinearity Statistics } \\
\hline Tolerance & VIF \\
\hline .968 & \\
.942 & 1.033 \\
.934 & 1.557 \\
Sumber: Data Primer Diolah, 2019 & 1.578 \\
\hline
\end{tabular}

b. Uji Analisis Linear Berganda

Dari hasil pengolahan data dengan menggunakan bantuan komputer program SPSS 24 for windows diperoleh hasil analisis seperti dalam tabel berikut: 
Tabel 06. Hasil Analisis Linear Berganda

Coefficients $^{\mathrm{a}}$

\begin{tabular}{|c|c|c|c|c|c|c|c|c|}
\hline \multirow[b]{2}{*}{ Model } & \multicolumn{2}{|c|}{$\begin{array}{c}\text { Unstandardized } \\
\text { Coefficients }\end{array}$} & \multirow{2}{*}{\begin{tabular}{|c|}
$\begin{array}{c}\text { Standardized } \\
\text { Coefficients }\end{array}$ \\
Beta \\
\end{tabular}} & \multirow[b]{2}{*}{$\mathrm{t}$} & \multirow[b]{2}{*}{ Sig. } & \multicolumn{2}{|c|}{$\begin{array}{l}\text { Collinearity } \\
\text { Statistics }\end{array}$} & \multirow[b]{2}{*}{ keterangan } \\
\hline & $B$ & Std. Error & & & & Tolerance & VIF & \\
\hline 1 (Constant) & 203.071 & 252.172 & & .805 & .432 & & & Tidak Signifikan \\
\hline MODAL & .613 & .152 & .706 & 4.041 & .001 & .968 & 1.033 & Signifikan \\
\hline USIA & .650 & 2.946 & .247 & 2.221 & .028 & .942 & 1.557 & Signifikan \\
\hline PENDIDIKAN & 41.260 & 39.308 & .227 & 2.050 & .035 & .934 & 1.578 & Signifikan \\
\hline
\end{tabular}

a. Dependent Variable: PENDAPATAN

Sumber : Data Primer Diolah, 2019

Berdasarkan tabel rekapitulasi tersebut, maka diperoleh persamaan regresi berganda sebagai berikut :

$Y=0,613 X_{1}+0,650 X_{2}+41,260 X_{3}$

Keterangan :

$\mathrm{Y} \quad=$ Pendapatan PKL

$\mathrm{X}_{1}=$ Modal

$\mathrm{X}_{2}=$ Usia

$\mathrm{X}_{3} \quad=$ Pendidikan

1) Nilai konstanta sebesar 203,071 mengindikasikan bahwa jika variabel independen yaitu Modal $\left(X_{1}\right)$, Usia $\left(X_{2}\right)$, Pendidikan $\left(X_{3}\right)$, nol maka Pendapatan Pedagang (Y) adalah sebesar konstanta 203,071.

2) Koefisien Modal $\left(X_{1}\right)$ sebesar 0,613 dimana setiap peningkatan Modal satu satuan akan mengakibatkan peningkatan Pendapatan Pedagang sebesar 0,613.

3) Koefisien Usia $\left(X_{2}\right)$ sebesar 0,650 dimana setiap peningkatan Usia satu satuan akan mengakibatkan peningkatan Pendapatan Pedagang sebesar 0,650 .

4) Pendidikan $\left(X_{3}\right)$ sebesar 41,260 dimana setiap peningkatan Pendidikan satu satuan akan mengakibatkan peningkatan Pendapatan pedagang sebesar 41,260.

c. Uji f (f-test) 


\section{Tabel 07. Hasil Uji f}

ANOVA $^{\text {b }}$

\begin{tabular}{|l|r|r|r|r|r|l|}
\hline Model & Sum of Squares & Df & Mean Square & F & \multicolumn{1}{c|}{ Sig. } & Keterangan \\
\hline $1 \quad$ Regression & 346487.836 & 3 & 115495.945 & 5.959 & $.000^{\mathrm{a}}$ & Signifikan \\
Residual & 310105.914 & 16 & 19381.620 & & & \\
\multicolumn{1}{|c|}{ Total } & 656593.750 & 19 & & & & \\
\hline
\end{tabular}

a. Predictors: (Constant), PENDIDIKAN, MODAL, USIA

b. Dependent Variable: PENDAPATAN

Hasil perhitungan analisis regresi berganda dengan SPSS diperoleh $F_{\text {hitung }}$ sebesar 8,338, sedangkan $F_{\text {tabel }}$ pada $a=5 \%$, sebesar 2,71; hal ini berarti $F_{\text {hitung }}>\mathrm{F}_{\text {tabel }}(8,338>2,71)$. Hal ini berarti bahwa $\mathbf{H}_{0}$ ditolak. Artinya Modal, Usia, Pendidikan berpengaruh terhadap Pendapatan PKL di Kelurahan Gading Kasri Kota Malang.

d. Uji t (t-test)

Tabel 08. Hasil uji t

\begin{tabular}{|c|c|c|l|}
\hline Variabel & $\begin{array}{c}\text { Koefisien } \\
\text { Regresi }\end{array}$ & Sig. & Keterangan \\
\hline Modal (X1) & 0.706 & 0,001 & Signifikan \\
\hline Usia (X2) & 0.247 & 0,028 & Signifikan \\
\hline Pendidikan (X3) & 0.227 & 0,035 & Signifikan \\
\hline
\end{tabular}

Sumber: Data Primer Diolah, 2019

1. Dapat diketahui bahwa variabel Modal (X1) memiliki nilai signifikansi 0,001 < a 0,05 dan nilai thitung 4,041 > tabel 1,724. Hal ini menunjukan bahwa Modal berpengaruh signifikan terhadap Pendapatan PKL di Kelurahan Gading Kasri Kota Malang. Dengan demikian, hipotesis pertama penelitian ini diterima.

2. Dapat diketahui bahwa variabel Usial (X2) memiliki nilai signifikansi 0,028 < a 0,05 dan nilai thitung 2,224 > tabel 1,724. Hal ini menunjukan bahwa Usia berpengaruh signifikan terhadap Pendapatan PKL di Kelurahan Gading Kasri Kota Malang. Dengan demikian hipotesis Kedua penelitian ini diterima. 
Dapat diketahui bahwa variabel Pendidikan (X3) memiliki nilai signifikansi $0,035<$ a 0,05 dan nilai $t_{\text {hitung }} 2,050>t_{\text {tabel }} 1,724$. Hal ini menunjukan bahwa Pendidikan berpengaruh signifikan terhadap Pendapatan PKL di Kelurahan Gading Kasri Kota Malang. Dengan demikian hipotesis pertama penelitian ini diterima.

\section{Diskusi Pembahasan}

\section{A. Pengaruh Modal Terhadap Tingkat Pendapatan Pelaku Usaha Skala Mikro}

Permodalan merupakan aspek penting dalam meningkatkan kapasitas usaha. Penelitian ini memperkuat argumentasi yang menyatakan bahwa tingkat modal yang tinggi akan berdampak signifikan pada perolehan imbal balik yang juga tinggi. Dari analisis regresi berganda, menunjukkan bahwa nilai koefisien regresi variabel modal adalah sebesar 0,706 atau bermakna positif, yakni apabila modal bertambah maka akan meningkatkan pendapatan. Hasil penelitian ini sekaligus memperkuat temuan dari Rossi (2014), bahwa permodalan yang tinggi sangat membantu ekspansi usaha pelaku skala mikro, sehingga tingkat profit akan meningkat. Meski demikian, harus diperlukan model tata kelola yang optimal agar suntikan permodalan yang meningkat dapat berkorelasi terhadap tingkat pendapatan. Raposo\& Paco (2011) menyatakan bahwa tata kelola pelaku usaha skala mikro, seperti pelaku informal membutuhkan model manajemen keuangan agar suntikan modal mampu berdampak positif terhadap perolehan pendapatan. Hal serupa juga dinyatakan oleh Njoroge (2013), yang menemukan bahwa pelaku usaha informal yang berhasil rata-rata dibekali oleh kemampuan menajamen usaha dan tertib keuangan.

Selain itu, signifikansi pengaruh modal dan tingkat pendapatan pelaku usaha skala mikro juga dipengaruhi oleh dampak yang dihasilkan oleh permodalan itu sendiri. Dengan skala permodalan yang meningkat, maka kegiatan produktif dari pelaku usaha juga meningkat, contohnya kemampuan produksi, pemasaran, dan penciptaan inovasi. Obebo, Wawiwe\& Muniu (2018) menemukan bahwa selama pelaku usaha meningkatkan kualitas permodalan, maka kegiatan usaha dapat mencapai keunggulan kompetitif lebih besar dan kinerja bisnis lebih tinggi. Keunggulan kompetitif mampu meningkatkan omset penjualan karena 
produk dan nilai tambah produk/jasa mampu menguasai pangsa pasar. Hal ini menunjukkan bahwa ketika usaha memiliki keunggulan kompetitif, maka kinerja usahanya akan baik dan menjamin kelangsungan hidup usaha. Dalam jangka pendek, tingkat profitabilitas langsung bisa diharapkan karena keunggulan bersaing berkorelasi positif dengan tren peningkatan pendapatan.

Selain itu, Sitharam\& Hoque (2019) juga mengamati hal serupa, dimana keunggulan kompetitif pelaku usaha adalah bersifat konsekuensial yang dapat digunakan sebagai ukuran konseptual bagi kinerja usaha khususnya pelaku UMKM. Pengukuran tersebut dispesifikasi khususnya melalui penerapan identifikasi sumber daya organisasi internal dan eksternal dalam meningkatkan posisi kompetitifnya. Hal ini berarti keunggulan kompetitif mampu berdampak pada pendapatan usaha. Kasus serupa juga dikemukakan oleh Aloum et.al (2016) bahwa permodalan mampu meningkatkan keunggulan kompetitif, dan keunggulan kompetitif mampu berpengaruh positif terhadap tingkat pendapatan UMKM. Kesemua penelitian tersebut semakin mempertegas bahwa suntikan permodalan terhadap pelaku UMKM, khususnya skalamikro seperti PKL mampu berpengaruh signifikan terhadap tingkat pendapatan.

\section{B. Pengaruh Usia Terhadap Tingkat Pendapatan Pelaku Usaha Skala Mikro}

Menurut Jayeola, Inhinmoyan\& Kazeem (2018), usia seorang pelaku usaha akan menentukan tingkat keberhasilan usaha. Hal ini disebabkan oleh kematangan berfikir dan pengalaman yang mampu menentukan langkah-langkah strategis dalam rangka memenangkan persaingan pasar. Temuan dari Gebremeskel (2014) mensinyalir bahwa pengaruh antara umur dan tingkat pendapatan dalam banyak kasus UMKM memang positif, namun signifikansinya sangat ditentukan kematangan berfikir. Dalam kasus tersebut, kematangan berfikir ditentukan oleh pembelajaran usaha. Contohnya, kekompakan tim produksi yang dihasilkan dari pembelajaran organisasi dari pengalaman kerja (umur), membutuhkan waktu yang cukup lama agar kinerja usaha yang dilihat dari parameter penjualan benar-benar bisa terlihat. Pembelajaran organisasi merupakan 
cerminan kematangan umur yang mampu berdampak pada kenaikan tingkat pendapatan.

Apa yang disampaikan Gebremeskel (2014) diperkuat oleh Margaretha\& Supratika (2016), bahwa faktor umur menentukan kapasitas seseorang untuk bertumbuh, begitupun dampaknya terhadap kinerja usaha. Semakin tinggi umur seseorang, maka terdapat kegiatan untuk meluangkan waktu untuk terus belajar mengembangkan usaha, sehingga pengetahuan mengenai peningkatan daya saing sudah sangat baik. Syaifuddin (2017) mengemukkan bahwa pengalaman kerja yang samakin tinggi (umur yang matang) merepresentasikan akumulasi pengembangan diri yang mengarah pada orientasi target atau hasil. Hubungan tersebut dikaitkan sebagai sebuah kematangan umur sehingga mampu melaksanakan pembelajaran diri, dan berimplikasi pada kesadaran diri untuk mencapai target kinerja yang diinginkan.

Uraian di atas telah menjelaskan bahwa umur pelaku usaha terbukti mempunyai keterhubungan yang kuat dengan kemauan untuk berkembang dan mampu berdampak positif terhadap peningkatan pendapatan. Kematangan umur mampu berpengaruh terhadap kinerja dan daya saing. Kinerja yang tinggi tercipta karena lingkungan pasar mampu dimanfaatkan oleh pelaku usaha dalam rangka mengakumulasi pengetahuan yang bermanfaat dalam konteks usaha. Korelasional ini sangat logis, mengingat kematangan umur adalah karakteristik diri yang melibatkan dimensi keterampilan. Dimensi tersebut merupakan pendorong tingginya tingkat kinerja usaha, karena pelaku usaha menjadi mampu untuk mengembangkan kapasitasnya.

\section{Pengaruh Pendidikan Terhadap Tingkat Pendapatan Pelaku Usaha Skala Mikro}

Menurut Chiliya\& Lombard (2012), tingkat pendidikan pelaku usaha mempunyai peran penting bagi penciptaan kualitas perumusan rencana bisnis dalam jangka panjang. Tingkat pendidikan mempunyai karakter yang hampir mirip dengan faktor umur, yakni sama-sama menentukan kualitas kematangan berfikir. Temuan dari Omerzel (2010) menguraikan bahwa tingkat pendidikan menentukan kematangan perencanaan dan bertindak, sehingga berdampak langsung terhadap kualitas daya saing, dan berakhir pada profitabilitas yang lebih tinggi. 
Selain itu, Zaino et.al (2015) juga mencoba meneliti dan menganalisis bagaimana tingkat pendidikan dikategorisasikan aset sosial sebagai sebuah sumber dari keunggulan bersaing. Penelitiannya menemukan bahwa tingkat pendidikan pelaku UMKM mampu menguji keefektifan evaluasinya dan kemampuannya untuk mengarahkan tindakan manajemen dalam mencapai keunggulan kompetitif berkelanjutan.

Penjelasan lain mengapa tingkat pendidikan mempunyai korelasi yang kuat dengan keunggulan bersaing adalah adanya kerja yang efisien dalam setiap komponen usaha. Kerja efisien merupakan perilaku yang menunjukkan upaya sungguh-sungguh dalam mengatasi berbagai hambatan guna menyelesaikan tugas dengan sebaik-baiknya (Visser, Nieman\& Heerden, 2015). Kerja efisien juga dimaknai sebagai suatu istilah yang melingkupi suatu upaya yang terus dilakukan dalam menyelesaikan target usaha dengan menerapkan prinsip biaya rendah (Virglerova et.al, 2017). Dalam kasus ini, kerja yang efisien diciptakan melalui tingkat pengetahuan yang tinggi, yang rata-rata didapatkan dari pendidikan yang ditempuh. Sitharam\& Hoque (2019) menyatakan bahwa tingkat pendidikan yang ditempuh pelaku UMKM mampu menghasilkan perilaku berusaha yang sungguh-sungguh dalam mengatasi hambatan dalam menyelesaikan pekerjaan atau dalam rangka mencapai target sasaran. Indikator dari perilaku berusaha adalah menyelesaikan semua tugas dengan baik dan tepat waktu. Beberapa perilaku tersebut mampu menciptakan keunggulan bersaing usaha, dan berdampak terhadap perolehan pendapatan.

\section{Penutup}

\section{A. Kesimpulan}

1. Pendapatan terendah PKL di lokasi penelitian adalah sebesar Rp. 40.000 dan pendapatan tertinggi sebesar Rp. 700.000 dengan ratarata sebesar Rp. 25.250. Ada perbedaan pendapatan yang cukup besar antar pedagang yang dilihat dari standar deviation sebesar Rp. 185.897.

2. Modal terendah PKL di lokasi penelitian adalah sebesar Rp170.000 dan modal tertinggi Rp. 950.000. Nilai rata-rata modal yang dimiliki sebesar Rp. 592.500. Modal antar pedagang satu dengan 
lainnya terdapat perbedaan yang cukup besar dilihat dari standar deviation sebesar Rp. 213.883. Variabel modal berpengaruh positif dan signifikan terhadap pendapatan PKL.

3. Usia terendah PKL di lokasi penelitian dalah 21 tahun dan usia tertinggi 70 tahun. Rata-rata usia pedagang kaki lima di kelurahan Gading Kasri Kota Malang usia 44 tahun. Variabel usia berpengaruh positif dan signifikan terhadap pendapatan PKL.

4. Variabel bebas modal, usia dan pendidikan berpengaruh signifikan terhadap pendapatan pedagang kaki lima di Kelurahan Gading Kasri Kota Malang.

5. Variabel pendidikan berpengaruh signifikan terhadap pendapatan PKL, yang ditunjukkan dengan nilai koefisien regresi sebesar 41, 260 sehingga pendidikan berpengaruh dominan.

\section{B. Saran}

1. Strategi pengembangan usaha skala mikro seperti PKL ke depan harus memperhatikan prinsip-prinsip permodalan dan pelatihan, yang diharapkan mampu berdampak pada optimalisasi pembelajaran organisasi, strategi berusaha, keunggulan bersaing, dan peningkatan kinerja usaha.

2. Dalam merancang strategi pengembangan usaha skala mikro seperti PKL sangat diperlukan program pelatihan dan pengembangan dalam rangka meningkatkan kapasitas pelaku usaha. Pengembangan dan pelatihan yang dimaksud termasuk upaya penerapan proses pemberdayaan, khususnya kepada pemilik usaha. Faktor pengembangan organisasi dapat dilakukan melalui penguatan manajerial dan keterbukaan terhadap segala akses informasi pasar. Pengembangan organisasi sangat penting dalam menentukan daya saing dan kinerja usaha, terutama bagi pelaku usaha skala mikro.

\section{Daftar pustaka}

Aloum, F., Abdullah, M.A., Moten, A.R.,\& Azam, S.M.F. 2016. Success factors of overall improvement of microenterprisesin malaysia: an empirical study. Journal of Global Enterprenership Research, Vol. 6, No. 7, pp. 01-13.

Chiliya, N.,\& Lombard, M.R. 2012. Impact of level of education and 
experience on profitability of small grocery shops in south africa. International Business, Vol. 3, No. 1, pp. 462-470.

Gebremeskel, Y. 2014. Determinants of profit variability among micro and small enterprises (mses) in zambia. International Journal of Economics and Finance, Vol. 6, No. 8, pp. 129-136.

Gimmon, E.,Yitsaki, R.,\& Hantman, S. 2018. Entrepreneurship in the third age: retirees' motivation and intentions. International Journal Entrepreneurship and Small Business, Vol. 34, No.3, pp. 267-288.

Jayeola, O., Inhinmoyan, T.,\& Kazeem, Y.K. 2018. Environmental factors and the performance of micro and small scale enterprises (smes) in nigeria: lessons from some selected mses in ondo state nigeria. Journal of Economics, Management and Trade, Vol. 21, No. 6, pp. 02-15.

Lateh, M., Hussain, M.D.,\& Halim, M.S. 2017. Micro enterprise development and income sustainability for poverty reduction: a literature investigation. International Journal of Business and Technopreneurship, Vol. 7, No. 1, pp. 23-38.

Margaretha, F.,\& Supratika, N. 2016. Factors affecting profitability of small medium enterprises (smes) firm listed in indonesia stock exchange. Journal of Economics, Business and Management, Vol. 4, No. 2, pp. 132137.

Mutoko, W.R.,\& Kapunda, S.M. 2017. Factors influencing small, medium and micro-sized enterprises' borrowing from banks: the case of the botswana manufacturing sector. Independent Research Journal in the Management Sciences, Vol. 17, No. 1, pp. 01-09.

Mustapa, W.N., Mamun, A.A.,\& Ibrahim, W.D. 2018. Development initiatives, micro-enterprise performance and sustainability. International Journal of Financial Studies, Vol. 6, No. 74, pp. 01-15.

Njoroge, J.M. 2013. The effect of entrepreneurial education and training on development of small and medium size enterprises in githunguri district-kenya. International Journal of Education and Research, Vol. 1, No. 8, pp. 01-22.

Obebo, F.M., Wawiwe, N.H.W.,\& Muniu, J.M. 2018. Effects of participation of micro and small enterprises in microfinance on their performace in kenya. International Journal of Economics and Finance, Vol. 10, No. 7, pp. 78-88.

Omerzel, D.G. 2010. The impact of knowledge management on sme growth and profitability: a structural equation modelling study. Africa Journal of Business Management, Vol.4, No.16, pp. 3417-3432.

Radipere, S.,\& Dhliwayo, S. 2019. The role of age and business size on small business performance in the south frican small enterprise 
sector. Problems and Perspectives in Management, Vol. 12, No. 4, pp. 0712.

Raposo, M.,\& Paco, A.D. 2011. Entrepreneurship education: relationship between education and entrepreneurial activity. Psichotema, Vol. 23, No. 3, pp. 453-457.

Rossi, M. 2014. Capital structure of small and medium enterprises: the italian case. International Journal Globalisation and Small Business, Vol. 6, No. 2, pp. 130-144.

Sitharam, S.,\& Hoque, M. 2019. Factors Affecting the performance of small and medium enterprises in kwazulu natal, south africa. Problems and Perspective in Management, Vol. 14, pp. 277-288.

Soekartawi. 2002. Faktor- faktor Produksi. Jakarta: Salemba Empat, hlm.132

Syaifuddin, A. 2017. The impact of creativity and innovation on incresing micro enterprise income pkl gading fajr sidoarjo. International Journal of Entrepreneurship and Business Development, Vol. 1, No.1, pp. 87-98.

Virglerova, Z., Dobes,K., Kramolis, J.,\& Kotaskova, A. 2017. The influence of sme owners education on their perception of business environmental in czezh republic. Interdisciplinary Approach to Economics and Sociology. Vol. 10, No. 3, pp. 321-332.

Visser B.T., Nieman,G.,\& Heerden, E.V. 2015. Financial administration and smalland medium enterprises: a study conducted in south africa. Athens Journal of Business nd Economics, Vol. 1, No. 3, pp. 181-192.

Waluyo. 2013. Perpajakan Indonesia. Jakarta: Salemba Empat.

Zaino, N.R., Mamun, A.A., Hassan, H.,\& Muniady, R.A. 2017. Examining the effectiveness of micro-enterprise development programs in malaysia. Journal of International Studies. Vol. 10, No. 2, pp. 292-308. 